\title{
$\mathrm{Al} /$ 接着剂モールド界面の疲労によるはく離進展挙動 ${ }^{\dagger}$
}

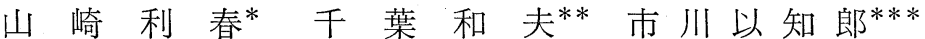

\section{Debond Growth Behavior of Al/Epoxide Moulded Interface by Fatigue}

by

\section{Toshiharu YAmAzAKI*, Kazuo CHIBA** and Ichiro ICHIKAWA***}

Fatigue tests were conducted on the moulded joints of aluminum and an epoxide adhesive material, and the debond growth behavior at its moulded interface pretreated in two different ways was observed. As the basic data, the fatigue crack propagation characteristics of the adhesive itself were experimentally obtained. The debond growth behavior at the interface by fatigue was predicted under the following conditions;

(1) The stress intensity factor of an interface crack is approximately equal to that of a crack in homogenious material as derived from the no-slip model proposed by Mak et al. ${ }^{1}$.

(2) The debond growth rate per cycle is equal to the crack propagation rate of the adhesive material.

(3) The residual stress on the moulded interface estimated by a photoelastic experiment and FEM analysis is taken into account as an influential factor for the stress ratio of fatigue load.

Fairly good agreement between the experimental and analytical results was found for the interface pretreated with sand-blast and chromic-acid. However the debond growth rate for the interface with no chromic-acid pretreatment was faster nearly by a factor of one order of magnitude than the prediction. Microscopic analyses of the debonded interfaces were conducted with SEM and X-ray microanalyzer and the debond growth mechanism was discussed.

キー・ワード：界面はく離, 疲労, 破壊力学

\section{1 緒言}

近年異種材料同士を接着して構造物を形成する技術 が広く普及し，接着界面のはく離が繰返し荷重の下で 進展する現象の解明が必要になってきている.

著者らは先に $\mathrm{Al}$ とエポキシ樹脂とをモールドによ り接合した継手の疲労試験を行い，その形状効果など を明らかにしたが，同時に界面のはく離は微視的に は $\mathrm{Al} /$ 接着層/エポキシ樹脂の三層構造の $\mathrm{Al} /$ 接着層 の界面に沿ったものであることを確認した．本研究は このはく離進展挙動を破壊力学的観点より明らかにす ることを目的として拉り, 現象を単純化するため本報 では $\mathrm{Al}$ と接着剤のみのモールド継手を用いた実験と 解析の結果について述べる.

界面き裂にはいわゆる振動特異性の問題が未解決て あったため，これまで異種材料の界面に沿らはく離進 展を破壊力学的に検討した例はきわめて少ない。しか し Mak らが提案したノースリップモデルによれば振 動特異性は消隇し, き裂先端の応力拡大係数としては $K_{\mathrm{II}}$ はゼロとなるが， $K_{\mathrm{I}}$ は均質体中のき裂のものに
近似的に等しくなる.このことは著者も FEM 解析に ノースリップ域を含めたモデルで確認している。 これ まで行われた接着継手の混合モード下の破壊実験では， $K$ 值よりもエネルギ解放率 $G$ で検討されることが多か ったが，一般的傾向としては $G_{\text {I }}+G_{\text {II }}$ は一定值にな らないことが知られている。 また Ripling らのモード I とIII の実験ではむしろ $G_{\mathrm{I}}$ が一定值で破壊する傾向 が見られる.このように過去の接着継手の破壊実験結 果は，界面き裂の進展はき裂上下面の相対すべりでは なく，き裂面の開口によりもたらされるとする $\mathrm{Mak}$ らのモデルを支持する傾向にある. このような状況か ら以下では $K_{\mathrm{I}}$ に基づいた解析を行い，はく離進展機 構につき検討する.

\section{2 実 験}

\section{$2 \cdot 1$ 試験片形状と試験片の製作}

Fig. 1 (a)(b)に実験に用いた試験片の形状を示す。(a) は接着剤の疲労き裂伝ぱ特性を求めるための片側切欠 き試験片である。ここで接着剤とは脂環式エポキシ樹 脂を二塩基酸を硬化剤として硬化させたもので，以下

$\dagger \quad$ 原稿受理 昭和62年1月 5 日. Received Jan. 5, 1987

* 正会 員 (株)東芝重電技術研究所 川崎市川崎区浮島町, Heavy Apparatus Engineering Laboratory, Toshiba Corp., Ukishima-cho, Kawasaki-ku, Kawasaki

**（株)東芝重電技術研究所 川崎市川崎区浮島町, Heavy Apparatus Engineering Laboratory, Toshiba Corp., Ukishima-cho, Kawasakiku, Kawasaki

*** (株)東芝ケミカル入般事業所 横浜市鶴見区, Irihune Works, Toshiba Chemical Co. Ltd., Tsurumi-ku, Yokohama 

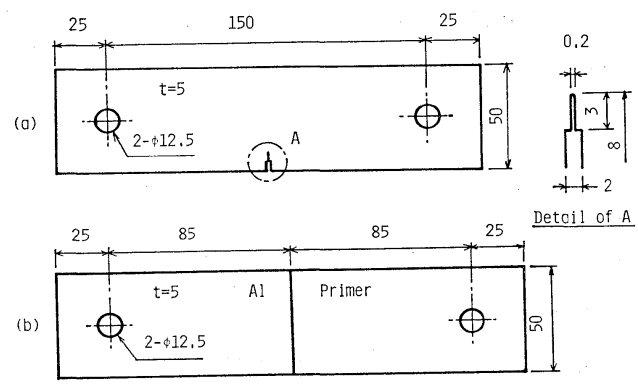

(a) Primer plate with single edge-notch.

(b) A1/primer moulded plate.

Fig. 1. Specimen geometry (dimensions in $\mathrm{mm}$ ).

プライマーと呼称する. プライマーを厚さ $5 \mathrm{~mm}$ の板 状に注形し，これより図に示守形状に機械加工した。 (b)は $\mathrm{Al} /$ プライマーモールド試験片で, 厚さ $5 \mathrm{~mm} の$ $\mathrm{Al}$ 板（A 5083）を同じ厚さのプライマー中にモール ドしてこれから機械加工を行った．また A 1 とプライ マーの界面処理としては，Al 面をサンドブラストに より粗化してからさらにクロム酸处理を行ったものと 行わないものとの 2 種類につき実験した．サンドブラ ストにより形成された $\mathrm{Al}$ 表面の凹凸は，深さが20〜 $40 \mu \mathrm{m}$ であった. 上記 2 種類の界面処理を, 以下単に, 酸処理有り，無しと略称する。また前報にて述べたよ らに $\mathrm{Al} /$ エポキシモールド継手の作製には, (1) $\mathrm{Al}$ 面に 塗布したプライマーの硬化(2)エポキシ樹脂の注形と加 熱硬化拈よび(3)アフターキュアの手順を経たが，Fig. 1 の試験片は(a)(b)ともこれと全く同じ熱履歴で作製し た. 最後に機械加工などのひずみを除去するため， $100^{\circ} \mathrm{C} \times 6 \mathrm{hr}$ の焼なましを行った。

\section{$2 \cdot 2$ 疲労試験方法}

Fig. 1 (a)の試験片を用いた疲労き裂伝ぱ実験は，電 気油圧式疲労試験機により応力比 $R=0,0.5$ 拉よび 0.7 について繰返し速度 $0.01 \sim 0.5 \mathrm{~Hz}$ で室温で行っ た。き裂長さはプライマーが透明であるので，背面 照明の下でき裂の斜め上方から接写写真撮影を行い $0.1 \mathrm{~mm}$ の精度で読みとった. Fig. 1 (b)の $\mathrm{Al} /$ プラ イマーモールド板のはく離進展実験は, 上と同じ治具, 同じ試験機にて $R=0$ (片振り) で $0.05 \sim 0.5 \mathrm{~Hz}$ で 行った。 また界面の端部にかるとりの刃を押付けるこ とにより，0.2〜0.1 mm の初期はく離を作った。は く離長さの測定は上と同様にプライマーを透過しての 接写写真撮影によった.

\section{$2 \cdot 3 \mathrm{Al} /$ プライマーモールド板の残留応力}

Al と土ポキシ樹脂のモールドによる注形残留応力 の解析方法については既に円板モデルの実験などによ りほ汴確立している。 しかし $\mathrm{Al}$ とプライマーだけの モールド板の注形残留応力については，これを解析の みで予測する十分なデータを持っていないので，光弾
性実験と FEM 解析とを併用して残留応力を推定した。

\section{3 実験結果および考察}

\section{$3 \cdot 1$ プライマー板の疲労き裂伝ぱ特性}

Fig. 2 にプライマー板の疲労き裂伝ぱ特性の実験結 果を示す。ここで伝ぱ速度 $d a / d N$ は，き裂長さ $a$ と 繰返し数 $N$ との曲線を図式的溦分して求めたるので

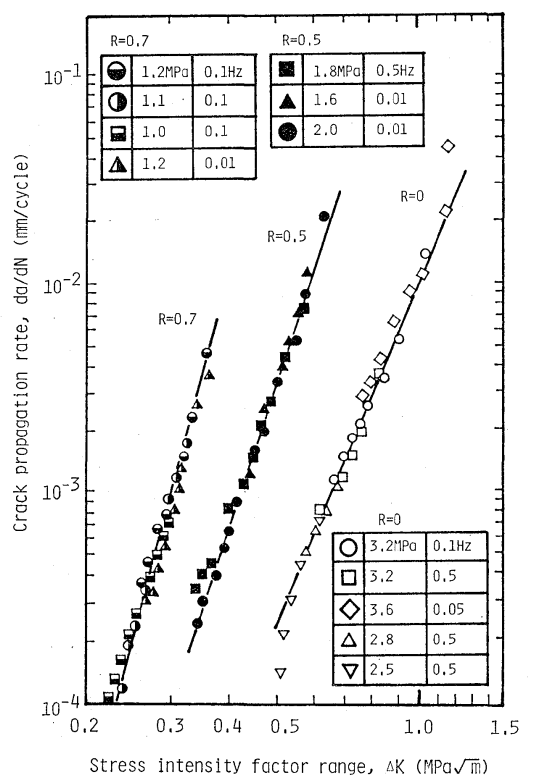

Fig. 2. Fatigue crack propagation rate vs. $\Delta K$ for primer plate.

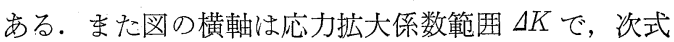
により計算した。

$$
\begin{aligned}
& \Delta K=K_{\max }-K_{\min } \\
& K_{\max }=\sigma_{\max } \sqrt{\pi a} F_{t}(a / b) . \\
& K_{\min }=\sigma_{\min } \sqrt{\pi a} F_{t}(a / b)
\end{aligned}
$$

ここに $\sigma_{\max }, \sigma_{\min }$ は公称疲労負荷応力の最大值, 最小值で，それぞれ引張荷重を試験片断面積で除した ものである。 $b$ は試験片の幅， $F_{t}$ は引張負荷に対す る幾何学的補正係数で，次式を用いた。

$$
\begin{aligned}
F_{t}(X)= & 1.12-0.231 X+10.55 X^{2} \\
& -21.72 X^{3}+30.39 X^{4}
\end{aligned}
$$

Fig. 2 飞は応力範囲 $\Delta \sigma\left(=\sigma_{\max }-\sigma_{\min }\right)$ と繰返し速 度とを示してある. $R=0,0.5$ 扝よび0.7kついての 実験結果は, 各 $R$ ごとに,

$$
\frac{d a}{d N}=A \cdot \Delta K^{m}
$$

となり，いわゆるパリス則により良く表される。ここ にA，mは Table I に示す定数である. 図より，プ ライマーのき裂進展速度は, 応力比 $R$ に対する明確な 依存性を示して扐り，また繰返し速度依存性はあまり 見られず，き裂進展が時間依存ではなく，繰返乙依 存であることが理解される. 図の結果を $\Delta K$ でなく， 
Table I. Fatigue crack propagation constants of primer. ( $\Delta K$ in $\mathrm{MPa}_{\sqrt{\mathrm{m}}}, d a / d N$ in $\mathrm{mm} /$ cycle)

\begin{tabular}{c|c|c|c}
\hline$R$ & 0 & 0.5 & 0.7 \\
$A$ & $1.038 \times 10^{-2}$ & $3.88 \times 10^{-1}$ & $3.15 \times 10^{1}$ \\
$m$ & 5.4 & 6.9 & 8.6 \\
\hline
\end{tabular}

$K_{\max }$ で整理し直してみたところ，各Rによる伝ぱ速 度データ間の差異は多少縮まる傾向があったが，dal $d N$ 対 $K_{\max }$ には依然として畋な $R$ 依存性が見られ た.

$$
\begin{gathered}
\text { ここで次のパラメータ } \lambda \text { 学導入する. } \\
\lambda=K_{\max ^{2}}-K_{\min ^{2}}
\end{gathered}
$$

Fig. 3 は疲労き裂伝ぱ速度をパラタータ入で整理し 直したもので， $R=0$ 〜 0.7 のすべてのデータが比較的

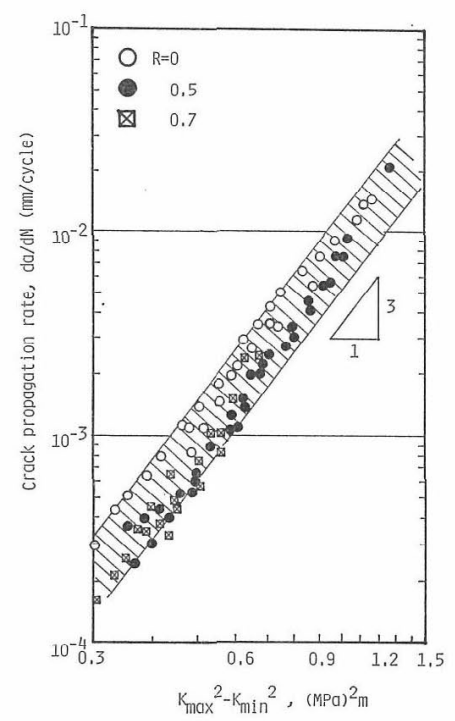

Fig. 3. Fatigue crack propagation rate $v s . K_{\max ^{2}}$ $K_{\mathrm{min}^{2}}$ for primer plate.

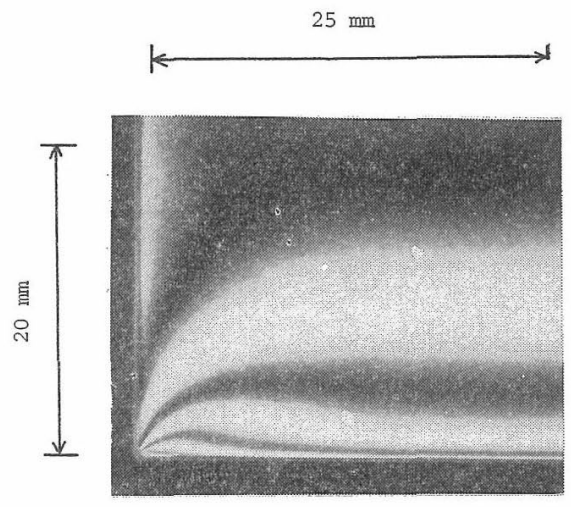

(a) Photoelastic experiment
狭い幅の斜線領域内にある。すなわち，伝ぱ速度はR を陽に含まない形で，次のように書ける。

$$
\frac{d \alpha}{d N}=B \cdot \lambda^{n}
$$

ここに $B=0.6 \sim 1.2 \times 10^{-2}, n \simeq 3$ であ. このよう な伝ぱ速度の $R$ 依存性は金属材料に新いて子一般的に 見られ，そのメカニズムとしては金属材料の場合はき 裂閉山現象が考えられている。 しかしプラスチック材 料の場合は式(4)の入による整理が一般的で，エポキシ， PMMA, ポリカーボネート招よびナイロン 66 などに ついて式(5)でまとめられることが確認されている.

\section{$3 \cdot 2 \mathrm{Al} /$ プライマーモールド界面近傍の残留応} 广

Fig. 1 (b)の Al/プライマーモールド板は機械加工後 ひずみとり焼なましを行った，しかしプライマーが硬 化してから室温までの泠却による収縮がA1 により阻 止されるため，界面近傍には熱応力が残留している。

$\mathrm{Al} /$ プライマー界面に平行に $x$ 軸, 引張軸方向に $y$ 軸をとる.モールド板は十分薄いので平面応力状態に 西る之考克て上く, 残留応力は $\sigma_{x x}, \sigma_{y y}, \sigma_{x y}$ の三成 分率る, この内, 界面に沿らはく離進展挙動に最子強 く影響すると考党られるのは $\sigma_{y y}$ である。

Fig. 4 (a) は，試験片のプライマー部分の光弾性実験 による等色線の写真の左半分で, 写真のしま模様は主 せん断応力，

$$
\tau_{\max }=\sqrt{\frac{1}{4}\left(\sigma_{x x}-\sigma_{y y}\right)^{2}+\sigma_{x y}^{2}}
$$

の等高線に対応したものである.プライマーの光弾性 応力感度 (しま次数/ $(2 \times$ 主せ九断応力 $\times$ 板厚 $)$ ) は, 引張試験より $0.037(\mathrm{MPa} \cdot \mathrm{mm})^{-1}$ であった。したが って, Fig. 4 (a)のしまの間隔は $2.7 \mathrm{MPa}$ の主せん断 応力差に対応する.

Fig. 4 (b)は FEM により熱残留応力を解析し，そ の結果から式(6)の主せん断応力の等高線を画いたもの

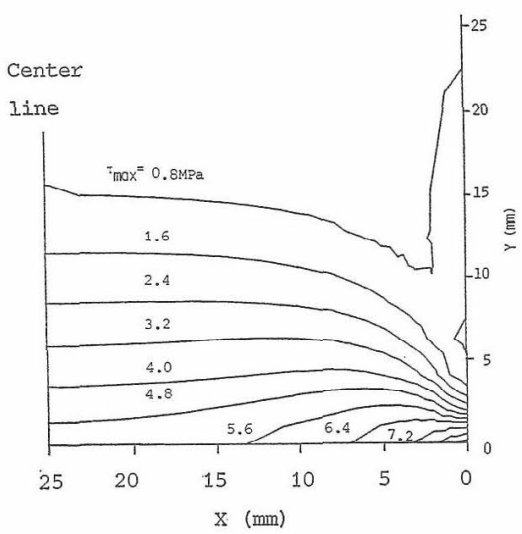

(b) FEM

Fig. 4. Isochromatic fringe patterns for primer part of $\mathrm{Al} /$ primer moulded plate. 
である。これは次のようにして計算した，Al/プライ マーモールド板の場合, 残留応力は硬化後の冷却熱応 カとして発生すると考兄られるが，物性值の温度依存 性など未知量が多い，そこでまず，任意の冷却熱収縮 ひずみとして， $-1 \times 10^{-3}$ (プライマーと $\mathrm{Al}$ の線膨張 係数の差 $=1 \times 10^{-5} /{ }^{\circ} \mathrm{C}$, 温度降下 $=-100^{\circ} \mathrm{C} ）$ を与光, 平面応力解析を行った，図は省略するが， $\mathrm{Al} /$ プライ マー界面近傍のメッシュサイズは $1 \mathrm{~mm}$ で，試験片外 周はすべて自由境界とした，構成材料のヤング率とポ アソン比は, Al では $70 \mathrm{GPa}, 0.3$, プライマーでは 室温での実測值， $2.5 \mathrm{GPa} ０ .4$ を用いた。

つぎに，界面から離れた部位での主せん断応力が FEM 解と光弾性実験結果とで一致するよう比例計算 を行ったところ，上の任意值の 4 倍が潘ぼ相当との結 果を得た. Fig. 4 (b)は試験片の右半分の主せん断応力 の等高線で，(a)(b)でパターンが非常に良く一致してい る. 界面上の残留応力成分 $\sigma_{y y}$ は上で計算した任意 值の 4 倍の結果から $\mathrm{Al}$ 側の要素の図心での值とプラ イマー側の要素の図心での値の平均値として求めた. $\sigma_{y y}$ を端部からの距離 $x$ に対してプロットしたものを Fig. 5 に示す. さらにこれを次の形の曲線で近似し最 小 2 乗法で係数を決定した.

$$
\sigma_{v y}=p+\frac{q}{x^{s}}
$$

その結果, $p=-1.70 \mathrm{MPa}, q=9.44 \mathrm{MPa} \cdot \mathrm{mm}, s=1$ で最もよく近似できた. $s=0.5$ や 2 は全領域での良 い近似とはならなかった。一般に異種材料の接合端部 では弾性応力は, き裂先端のものより複雑な特異性を もつことが知られている. 上式には FEM 解析結果を 一本の曲線で近似した便宜的なるのである. また $x=$ 0 で $\sigma_{y y}$ は上式では発散するが，実際にはプライマー の塑性変形などのため有限値にとどまると考兄られる.

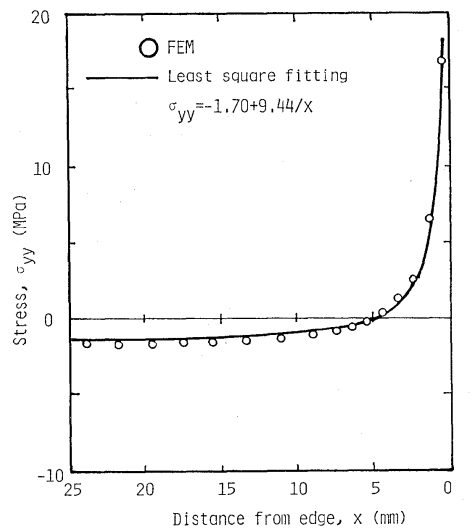

Fig. 5. Debonding stress distribution along the moulded interface.

\section{$3 \cdot 3 \mathrm{Al} /$ プライマー界面のはく離進展挙動}

Fig. 6 (a) 亿示すように幅 $b$ の試験片に長さ $a$ のはく 離がある場合を考学る. 界面上の応力は, 負荷応力に 式(6)の残留応力が重畳されたものになる。 まず界面さ 裂の $K$ 值が均質体中のき裂の $K$ 值に等しいとして議論 をすすめる。，一様負荷応力 $\Delta \sigma$ による $K$ 值は，

$$
K_{\mathrm{I}}=\Delta \sigma \sqrt{\pi a} \cdot F_{t}(a / b)
$$

となる.ここに $F_{t}$ は式(2)の一様引張りに対する幾何 学的補正係数である。つぎ残留応力分布に対しては, 罒示したようにき裂先端を基準として直線近似し，引 張成分 $\sigma_{t}$ と曲げ成分 $\sigma_{b}$ とに分解してK 值を評価す る. 式(7)の場合は， $\sigma_{t}$ は $(p+q / a)$ となる。 $\sigma_{b}$ は式 (7)の双曲線の接線をとると $q / a$ となる. 乙かし, 双曲 線状応力分布では応力こう配が非常に大きいため，き 裂先端相当位置の接線で直線近似して $K$ 值を評価する ことによる誤差が特に $a$ が大きくなるにつれて増加す ると考光られる。白こでこれをさけるため Fig.6 (b) に示すように接線ではなく, 便宜的に $x=a$ 上の点と

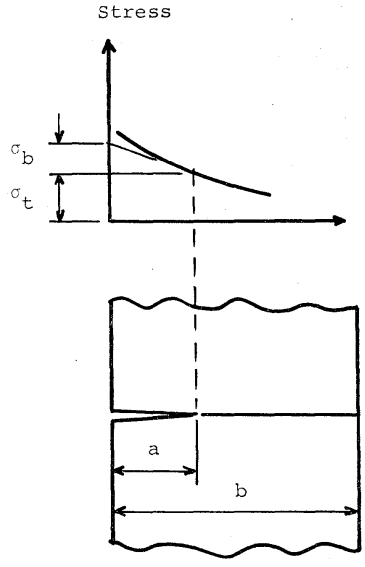

(a)

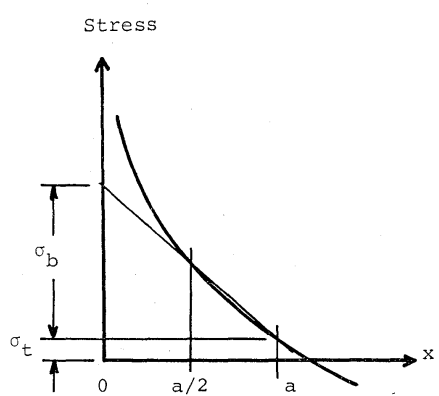

(b)

Fig. 6. Bimaterial plate with interface crack and stress state on the interface. 
$x=a / 2$ 上の点を結ぶ直線で近似する．このとき $\sigma_{b}=$ $2 q / a$ となり, 結局残留応力によるK值は次式となる。

$$
K_{2}=\left\{\left(p+\frac{q}{a}\right) F_{t}+2 \frac{q}{a} F_{b}\right\} \sqrt{\pi a}
$$

ここに $F_{b}(X)$ はさ裂先端相当位置で応力が 0 となる 非刘称曲げに対する補正係数で, 式(2)の $F_{t}(X)$ と, 対称曲げの補正係数 $F_{0}(X)$ とから, 次式により合成 できる。

$$
F_{b}=F_{t}+\frac{\left(F_{0}-F_{t}\right)}{2 X}
$$

$F_{0}$ としては，例党ば次式が知られている。

$$
F_{0}(X)=1.12-1.40 X+7.33 X^{2}
$$

$$
-13.08 X^{3}+14.0 X^{4}
$$

式(2)，(11) 老式(10)に代入したものは，式(10)右辺第 2 項の 引算と $X$ にる除算のため $X<0.1$ での精度がやや劣 る. そこで $F_{b}$ としては， $X<0.1$ での精度をこれよ りる改善した次式を用いた。

$$
\begin{aligned}
F_{b}(X)= & 0.441-0.609 X+8.10 X^{2} \\
& -14.57 X^{3}+18.27 X^{4}
\end{aligned}
$$

式(9)の導出に関しては, 残留応力のはく離進展に伴ら 再配分は考慮していない，前節で検討したように， Al/プライマー界面に存在する残留応力は, 基本的に は弾性熱応力で步り, はく離の進展に伴い去の分布形 は変化すると考光られる。しかし，一般に，K值はき 裂を導入する以前の応力分布が基になって決定される ので, 弹性熱応力に関する限り, 式(9)にて係数 $p, q$ をき裂長さによらず，一定值としてょい。

したがって式(4)のパラメータ入は次式となる。

$$
\lambda=\left(K_{1}+K_{2}\right)^{2}-K_{2}{ }^{2}
$$

ここで界面のはく離進展速度がプライマー中の疲労き 裂伝ぱ速度の式(5)に従らるのと考光る。そうすると初 期はく離長さ $a_{0}$ から 要する繰返し数 $N$ は次式で与兄らる。

$$
N=\int_{a_{0}}^{a}\left(B \cdot \lambda(a)^{n}\right)^{-1} d a
$$

さて前述したように，Mak のモデルによれば，は 〈離の全域がンースリップ域である場合は，界面き裂 の $K$ 值注均質体中の裂のK值に一致する。しかしそ らでない場合は，近似的に等しくなるがその近似度は ノースリップ域の割合と被接着材同上のヤング率の比 率 $\left(E_{1} / E_{2}\right)$ に依存することになる。ここに $E_{1}, E_{2}$ は Al とプライマーのヤング率で $E_{1} / E_{2}=28$ である。 Mak の計算でほ $1 \%$ 以下のノースリップ域で $E_{1} / E_{2} \sim$ 15 の場合約 $9 \%$ 低めになりまた修正き裂閉口積分法 による検討では FEM モデルにノースリップ域を含め ないで $E_{1} / E_{2}=7$ の場合約 $5 \%$ 低めとなった. 界面き 裂のK值の計算に均質体中のき裂についての变位法を そのまま適用した解析るあり，炎れによると $E_{1} / E_{2}=$ 10 とて約 $8 \%$ 低奴なっいる. 今の場合 $E_{1} / E_{2}$ は
かなり大きく，またはくりの全域がノースリップ域で 兆るとは考光にくいので，やはりヤング率比の大きさ を考慮して式(9)の $K_{1} ， K_{2}$ 索10\%低めにして計算した。 Fig. 7 に疲労による济進展状沉の写真を示す. Fig. 8 飞実験結果と式(14)による計算結果とを比殡した。 図中の斜線は式(5)のBの幅に対応したるのであるが, 計算值同士の重なり合いをさけるため $B$ の中值士 25 \%の範围の夕図示した，界面処理がサンドブラストの みのものでは実験結果は理論上りも一けたほど速い。

しかし酸処理を行ったものでは実験結果と理論の一致 はよく，応力範囲と破燷までの繰迈し数の括括よ气が 予測されている。

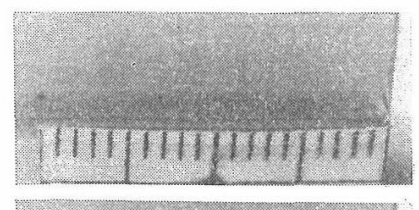

(a) $\mathrm{N}=0$
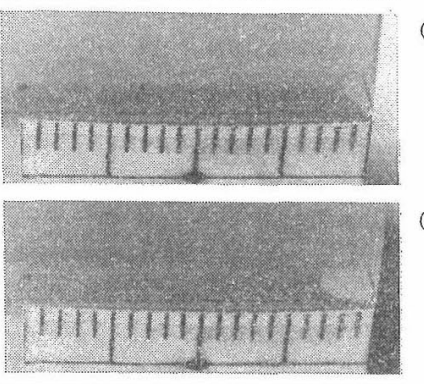

(c) $\mathrm{N}=13500$

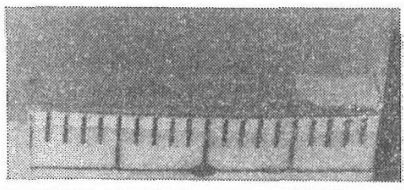

(d) $\mathrm{N}=16900$

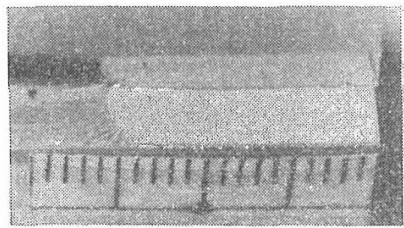

(e) $N_{f}=18200$

Fig. 7. A series of photographs showing the growth of debond of Al/primer moulded interface. $(\Delta \sigma=3 \mathrm{MPa})$

\section{$3 \cdot 4$ はく離面の SEMI 䚑察とはく離進展機構の検 討}

Fig. 9 と Fig. 10 飞酸処理無し, 有りのはく離面 のSEM 写真学示す。各図之も(a)は Al 側，(b)はプラ イマー側のはく離面で岗る。通常プラスチック材料の 破面の SEM 観察では金を破面上飞蒸着して行らが, Fig.9 (a)だけは無蒸着のまま钼察した。これはA1 面 に付着しているプライマーを識別しやすくするためで, 電子線の照射によりプライマーには電荷がチャージさ れ金属部よりも多くの 2 次電子発発生するためプライ マー部が眀るく観察される。 


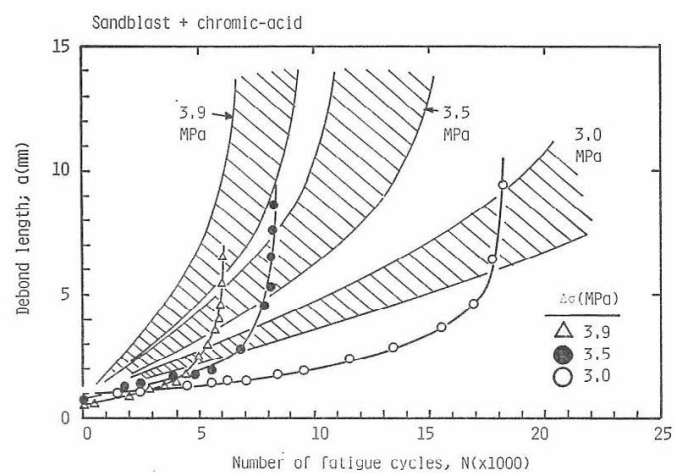

(a) Along the interface pretreated with sandblast and chromic-acid.

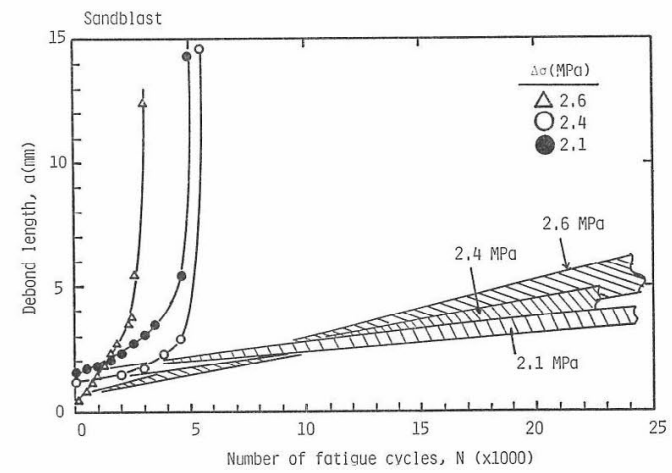

(b) Along the interface pretreated with sandblast.

Fig. 8. Comparison of debond growth behavior between experiment and theory.

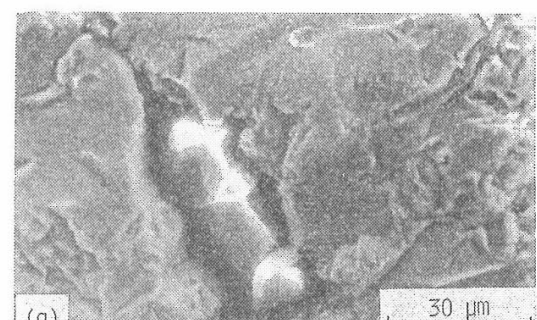

(a) $30 \mathrm{fm}$

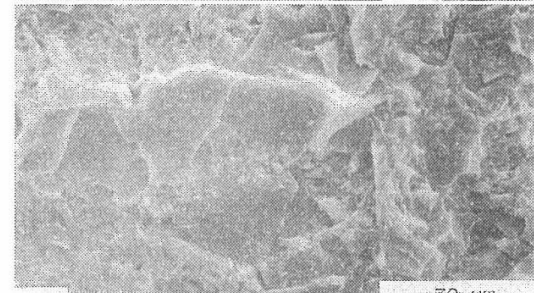

(b)

(a) Al side observed with no gold-coating.

(b) Primer side.

Fig. 9. SEM photographs of debonded interface pretreated with sandblast.

$\mathrm{A} 1$ 側のはく離面上には酸処理の有無に拘らず， $\mathrm{Al}$ 面の凹部に取込まれたプライマー（これをアンカー部 と呼ぶ）の切断跡が残っている. 従来から接着部のは

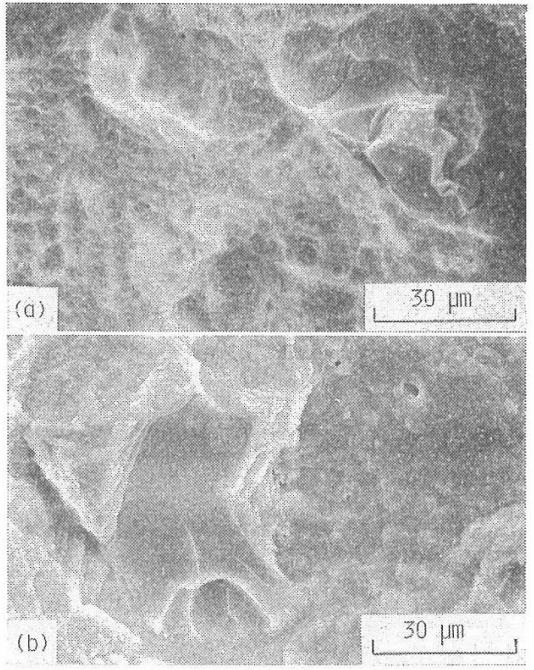

(a) A1 side. (b) Primer side.

Fig. 10. SEM photographs of debonded interface pretreated with sandblast and chromic-acid.

く離抵抗の機榡として投錨によるメカニカルインター ロックが考えられている。しかしアンカー部の全面樍 に占めを比率は10\%以下であり，また酸処理の有血に よる有意差子㐫まり認められない。つまり面積比率か ら判断すると酸好理の有無に上るはく離進展速度の差 や，酸処理品についての理論との一致などについては アンカー部よりもむしろアンカー部以外の部分のはく 離進展抵抗の方がより重要な意味をもつと考光られる。

$\mathrm{Al}$ 側のはく離面上のプライマー未付着領域では, Fig. 9 (a)ではサンドブラストによる粗い四凸が見られ， Fig. 10 (a)ではサンドブラストによる阴凸が滑らかに なっているのが見えるが，これは酸処理によるもので ある、はく離面の $\mathrm{Al}$ 側とプライマー側とでは基本的 には面の川円它反転させた特徽が見られると考党られ る.したがってプライマー未付着領域で両者を対比す ることにより初期欠陷の有無などを知ることができる 可能性がある。Fig. 10 では酸処理により滑らかにな った Al 面の䧃部がプライマー側に円部となって転写 されて和り，一部に直径数 $\mu \mathrm{m}$ 程度の小ボイドがプラ イマー側に見られるが初期欠陷はかなり少ないと推定 される.これに対して Fig. 9 では(a)(b)の対応は明ら かではない.サンドブラストによる Al 面の鋭い凹凸 はその李プライマー側に転写さ机て和らず，初期か ら界面上に多数の欠陥が存在した可能性が高い。つ采 り酸処理の有無によるはくり進展速度の差は, 界面処 理方法の違いによる界面上の初期欠陷密度の差により もたらされている可能性が高いと考えられる。

つぎにはく離面のアンカー部以外の部位にて約 $10 \mu \mathrm{m} \times 10 \mu \mathrm{m}$ のスポットの X線マイクロアナライザ (XMA) による分析を行ったところ，随所で毎秒10〜 
30カウントの炭素が検出された. アンカー部のプライ マーの切断跡では数キロカウント／秒であり，はく離 面以外の $\mathrm{Al}$ 面（試験片側面など）ではほぼ０カウン トであることを確認した。また酸処理の有無で炭素検 出カウント数に大差はなかった. ここで検出した炭素 は Al 面に付着しているプライマーからのものと考光 られ，アンカー部以外の部位に沶いても SEM では観 察できないような極薄いプライマーの層を残してはく 離が進展していることを示唆している，同様な結果は Bascom らも $\mathrm{Al} /$ エポキシのはく離面について得てい る. 彼らは $\mathrm{Al}$ のはく離面のオージェ分析を行い，数 $10 \mathrm{~nm}$ 程度のエポキシ樹脂がはく離面上に残留してい ると結論付けている。一般に巨視的には界面破壊でも 微視レベルでは完全な界面の分離ではない場合が多く, 特に $\mathrm{Al}$ に酸化皮膜が形成されていると土ポキシとの 界面結合力が高くなり，微視レベルでは必ず接着剤が 破壊するといら報告がある.

前節では界面のはく離進展速度がプライマーの疲労 き裂伝ぽ速度式(4)に従うと仮定しその予測を行った. このよらな状況は，例觉ば巨視的なレベルでの界面破 壊が微視的には界面から少しプライマー側に入った部 分を進展するいわゆる接着破壊である場合に相当する が，上の XMA による分析結果はこの考觉を裏付け るものである。また界面強度が接着剤の強度よりも高 い場合はこのよらな状況は実現しらると考兄られるの で，その意味からは式(14)ははく離進展速度の下限值を 予測するものとして合理的である.

ただし界面近傍の欠陷密度が高くなるとはく離進展 速度は式(14)よりも加速されることが考觉られる．界面 上の欠陷は正味応力を高め, はく離先端の $K$ 值を局所 的に高める効果をるつと考学られるから， はく離進展 挙動は界面上の欠陷密度に大きく左右されるであろう. 式(4)(5)から,

$$
\frac{d a}{d N} \propto \Delta \sigma^{2 n}\left(1+2 \frac{\sigma_{\text {res }}}{\Delta \sigma}\right)^{n}
$$

であった.ここに $\sigma_{\text {res }}$ は式(7)の残留応力であり，正 味断面積に対する負荷応力 $\Delta \sigma$ とともに欠陥の存在に より影響をうける。この程度は $\sigma_{\text {res }}$ と $\Delta \sigma$ の両方に 対してほぼ同程度と考えられるので上式右辺第 2 項へ の寄与は小さい，つまり第 1 項が支配的で $n=3 \sim 4$ で あるから上式よりはく離進展速度は $\Delta \sigma$ の 6 ～ 8 乗に 比例することになる．例壳ば酸処理無し品の場合，正 味断面積が25\%減少するとはく離進展速度は3.8〜6.0 倍となり，ほぼ一けた速くなることが理解される。こ れに対して酸処理品で湔述したように界面上の欠陥 密度は低く, 式(14)による理論に近いはく離進展挙動を したものと考えられる。

$$
4 \text { 結言 }
$$

$\mathrm{Al}$ とプライマーのモールド継手界面の疲労による はく離進展実験を行い，プライマー単独での疲労き裂 伝ぱ特性に基づくはく離進展速度の解析結果と比較検 討した.ただしここでは界面さ裂のK值として，ヤン グ率比の大きいことを考慮して均質体中のき裂の $K$ 值 の10\%低めの值を用いた. またはく離面の SEM 観察 やXMA に上る炭素分析を行いはく離進展機構につ いて検討した．それらの結果を総合すると，

(1) はく離進展は接着破壊であって，それゆ光はく 離進展特性は接着剂の疲労き裂伝ぱ特性を基にしたも のである.

（2）乙かし，界面上の欠陷密度が高くなる界面処理 方法の場合は, 正味断面積の増加などによりはく離進 展速度が加速される.

などが結論として導かれそらである。乙かし本研究で の理論と実験の比較は $a-N$ 関係の概略に関するもの であり，また実験データの中には一部理論よりも減速 側になるものも見られた. したがって加速要因のみで なく, 減速要因についての検討も今後必要となろら.

（昭和61年11月13日 第18回疲労シンポジウムにて講演）

\section{参 考 文 献}

1) A. F. Mak, L. M. Keer, S. H. Chen and J.L. Lewis, J. Appl. Mech., 102, 347 (1980).

2）山崎利春，千葉和夫，市川以知郎，材料， $\mathbf{3 5}, 158$ (1986).

3) 田中道七, 堀美知郎, 日本機械学会論文集, A-47, 131 (1981).

4) 山崎利春, 材料, 34, 1261 (1985).

5) A. J. Kinloch, J. Mat. Sci., 17, 617 (1982).

6) F. Flasher, S. Kenig, I. G. Zewi and H. Dodiuk, Eng. Frac. Mech., 21, 997 (1985).

7) G. G. Trantina, J. Com. Mat., 6, 371 (1972).

8) E. J. Ripling, J.S. Santner and P. B. Crosley, J. Mat. Sci., 18, 2274 (1983).

9）山崎利春, 大沼秀夫，材料， 33，980 (1984).

10) H. Tada, P.C. Paris and G. R. Irwin, "The Stress Analysis of Cracks Handbook" (1973) Del Research Corp.

11) S. A. Sutton, Eng. Frac. Mech., 6, 587 (1974).

12) S. Arad, J. C. Radon and L.E. Culver, Eng. Frac. Mech., 4, 511 (1972).

13) 平 修二監修, “現代材料力学”, 第12章 (1970) オーム 社.

14）畑 敏雄, 日本機械学会誌, 87, 233 (1984).

15) A. J. Kinloch, J. Mat. Sci., 15, 2141 (1980).

16) W.D. Bascom, C. O. Timmons and R. L. Jones, J. Mat. Sci., 10, 1037 (1975).

17) J. D. Venables, J. Mat. Sci., 19, 2431 (1984).

18）山崎淳一, 結城良治, 北川英夫, 日本機械学会論文集, A-52, 963 (1986). 